\title{
ATOMIC PHYSICS IN NORTHERN EUROPE
}

The Danish Atomic Energy Commission

$T$ HE fifth annual report of the Danish Atomic Energy Commission* covers the period April 1, 1960-March 31, 1961. It describes the building operations at the Riso Research Establishment and the work of the six sections of the Establishment; the reactors $D R 1, D R 2$ and $D R 3$; international cooperation in the peaceful uses of atomic energy through the International Atomic Energy Agency; regional co-operation in Europe through the Organization for European Co-operation and Development and the European Atomic Energy Society; Nordic co-operation through the Nordic Liaison Committee for Atomic Energy; and various other activities including geological surveys in Greenland, educational and training courses, and general information services.

During the period under review there was no change in the membership of the Commission. Prof. Niels Bohr and Dr. H. P. Christensen continued as chairman and vice-chairman respectively and $\mathrm{H}$. $\mathrm{H}$. Koch, permanent under-secretary of State, as chairman of the executive committee. By the Royal decree of March 26, 1960, the jurisdiction of the Commission was transferred from the Minister of Finance to the Prime Minister. The total staff of the Commission on March 31, 1961, numbered 643, of which 420 were employed in the technical and scientific division and distributed over various sectionsreactor, physics, electronics, radiation, agricultural research and the three reactors. The secrotariat consisted of a staff of twenty-two at the central office of the Commission at the Christiansborg Palace and of thirty at the subsidiary office at the Establishment.

After the completion of the third and biggest reactor $D R 3$ in the beginning of 1960 , building operations were concentrated on various supplementary installations required for the work at the Rise Research Establishment. These included a hot-cell facility, begun in August 1960, and the planning of expansions of certain laboratories, the construction of which commenced in March 1961. Research work, which was extended considerably when the big reactors came into operation, continued to develop, especially in connexion with a series of joint research projects on which the Commission has embarked in co-operation with other national and international atomic energy organizations. The Deuterium-moderated Organic-cooled Reactor study project has provided opportunity for study of the optimalization procedure and technical difficulties in the construction of an organic-cooled type of reactor, and participation in the two joint European projects, Dragon and Halden, has provided opportunity for following important aspects of development in the field of high-temperature gas-cooled and boiling-water types of reactor. Power production with breeder reactors, plutonium recycling and nuclear ship propulsion have not as yet been investigated at Risø. Neither has the Commission engaged much in fusion research, but both theoretical and experimental studies in plasma physics are being undertaken at Risø.

* Report on Activities of the Danish Atomic Energy Commission for the period from 1st April, 1960, to 31st March, 1961. Pp. 70 (Copenhagen: Danish Atomic Energy Commission, 1961.)
The physies department of the Establishment consists of the physics laboratory, the meteorology station, the reactor $D R 1$ and the linear accelerator laboratory. During the year the linear accelerator was used for an extensive series of irradiation experiments for the Atomic Energy Commission and for industry. This has been reported in Risø Report No. 16. A group continued on the construction of a laboratory for the investigation of $\beta$ - and $\gamma$-radioactivity, with the particular view of measuring the fundamental experimental constants of the $\beta$-radioactivity of the neutron. The solid-state group carried out intensive work on radiation damage, and some preliminary work on radiation damage to graphite at very low temperatures was commenced. The group working on problems of plasma physics and the utilization of the energy of fusion obtained data from a series of studies of electromagnetic shock waves using an instrument designed for this purpose. An international summer school course in plasma physics was held. This was arranged with the economic support of the Advanced Study Institute Program of the North Atlantic Treaty Organization, and of the Rask-Oersted Foundation. The course lasted 14 days and was attended by 130 delegates from 24 countries.

In the electronics department an experimental set-up was arranged in order to study the stability of photomultipliers and a recording single-channel pulse-height analyser mainly intended for use in $\gamma$-ray spectroscopy was developed. In addition to other work of a research and development character, work was carried out on nano-second photography using an image-converter tube, and a radio-altimeter was incorporated in the scintillometer used by the Greenland Geological Survey for uranium prospecting in Greenland. A new development within the electronics department was the introduction of a group for industrial instrumentation, the task of which was to advise on and plan experiments requiring conventional industrial control instrumentation. Since its establishment the group, consisting of two graduate engineers and two technical engineers, has worked on a testing cabinet for Wigner rigs; regulating equipment for the Wigner calorimeter; instrument panels for experiments in heat transmission in helium; and instrumentation for the $S A P-2$ experiments. In the annual report details also are given of the activities of the reactor engineering, chemistry and health physics departments.

A separate chapter of the Report deals with international co-operation in the peaceful use of atomic energy. This is discussed under the headings of the International Atomic Energy Agency; and regional co-operation in Europe, including the Organization for European Co-operation and Development, European Atomic Energy Society and Nordic co-operation. In addition to its direct educational and training activities in technical and scientific subjects the Commission tried to satisfy general public interest in nuclear energy and in the Riso Research Establish. ment by publications, radio and television broadcasts, and by conducted tours of the Establishment. During the period under review about ten thousand persons visited Riso. On March 31, 1961, the Library of the 
Establishment contained 74,000 bibliographical units, including 66,000 reports of which 25,000 were on microcards. On October 1, 1960, the Library engaged a librarian to act as adviser on Russian.

The report concludes with a list of publications by members of the staff of the Commission and with a detailed map of the layout at the Riso Research Establishment.

Nordic Institute for Theoretical Atomic Physics

The third annual report of the Nordisk Institut for Teoretisk Atomfysik (NORDITA)*, which contains both Danish and English versions of the text and covers the period July 1, 1959-June 30, 1960, reports the work continued on the same lines as provious years. The organization still oporated on an interim basis, pending the working out by the committee, appointed by the Governments of the member countries (Denmark, Finland, Iceland, Norway and Sweden) and the Nordic Council, of the general *NORDITA: Nordisk Institut for Teoretigk Atomfysik Arsberentning 1959/60 (Annual Report). Pp. 45. (Copenhagen: NORDITA Blogdamsvej 17,1962 , ) principles for tho administration of joint Nordic institutions. During the year the board consisted of four members from Denmark, Finland and Norway, respectively, three from Sweden and one from Iceland, with Prof. Niels Bohr as chairman. The staff comprised Prof. C. Moller as director and four scientific and four administrative staff. Thore were fourteen research fellows, six of whom had had their fellowships extended for a second year. Eleven research fellows and a member of the staff of Nordita, together with other Danish and Swedish physicists, undertook a week's study trip to Geneva for the purpose of a visit to CERN. The report concludes with nine appendixes in which are listed the various publications and lecture notes issued by the Institute during the year; the colloquia and courses of lectures hold; the lectures given by visiting foreign physicists; the visits paid by members of the staff of the Institute to other institutions and tho attendance of staff and research follows at congresses and meetings; and the visits paid by the research fellows to their home institutions.

\section{LONG-TERM PLANNING OF RESEARCH IN JAPAN}

$I^{\mathrm{N}}$ 1954 the Science Couneil of Japan, a body consisting of 210 members, formed a committee for long-term planning of research. This committee did its main work between 1954 and 1956, but is still continuing its investigations; among its original members were the chairman (Prof. Arisawa), who is an economist, and three secretaries-ono an economist (Prof. Tsuru), the second an agricultural scientist (Dr. Fukushima) and the third a mathernatical statistician (Prof. Kitagawa). The Committee was concerned with recommendations on population, food, energy, industrial techniques and fundamental sciences.

Prof. Kitagawa has summarized, in the January issue of the Australian Journal of Science, the White Paper on Research, published in 1956 by the Science Council of Japan, which deals with fundamental science.

The method of investigation was that of questionnaires to individuals and institutions, issued with the co-operation of national committees in the various sciences. These consisted of two overlapping sections, the furst endeavouring to obtain objective information about the departments in which the individuals concerned were working, and the second part asking for suggestions for the improvement of the departments and of Japanese science in general. The results were then submitted to leading experts in each field investigated, and, after this check, proposals were made to meet the problems outliner.

The recommendations were: (1) To raise the general standard of training and research in universitios and research institutes by increasing their budgets, and improving their staff position and equipment. (2) To encourage co-operation among university research workers and promote the common uses of apparatus and facilities, partly in order to avoid unnecessary duplication of expensive equipment. (3) 'The liquid scheme'-a proposal for the establishment of central institutes in specialized topics, which would allow the easy exchange of staff between universities and the institutes. The advantages of this scheme would bo improved communication between scientists, and considerable savings on equipment which could be located at the central institutes. (4) The uses of National Committees in respective sciences for discussion of important problems in their ficlds, and the planning of future dovelopments. (5) Availability to the public of all Governmental data and scientific publications.

The Japanese Government has already taken some steps to meet the first recommendation, the second has been partly realized, the third has been estab. lished though with a moro moderate budget than had been proposed; recommendations 4 and 5 still await full implementation.

In 1959 a report entitled "The White Paper on Fundamental Science, No. 1" was brought out; this pointed out that the development of fundamenta] science was essential to technical innovation. Japan was lagging badly in the sciences and, unless strong steps were taken, there was a danger that the country would fall farther below international levels. The White Paper contains a discussion of budgets for the pure and applied sciences, including a comparison of total expenditure for these soiences in Japan with the equivalent expenditures in the United States, the U.S.S.R., the United Kingdom and Western Germany. A comparison with these countries of the ratios: (a) budget for sciences/total Government budget, and (b) budget for sciences/total national income, showed that Japan's relative expenditure was lagging. An example was also quoted of a particular department showing that only about one-third of the total budget set aside for the sciences, less administrative and other costs, finally found its way to the scientists themselves. A study of the numbers of scientific staff showed that, in 1957, in the Faculty of Engineering of the University of Tokyo, 72 per cent of the scientific equipment was antiquated (dating before 1925). Examination of tho research system in universitios showed that the yearly system of funds and accounts was unsuitable for long-term planning of research. Moreover, the 